\title{
Web 上における効果的なナビゲーションシステムの考察
}

松本 賢木 (慶応義塾大学総合政策学部)、福田忠彦（同大学環境情報学部）

\author{
A study on the effective Web navigation System \\ Masaki Matsumoto (Faculty of Policy Management, Keio Univ.), \\ Tadahiko Fukuda (Faculty of Environmental Information, Keio Univ.)
}

\section{1. 研究目的}

情報技術の発達に伴い、インターネットユー ザは増え続けている。しかし、ウェブはまだ発 展途上のメディアであることは否めず、時には、 ユーザが欲しい情報を手に入れるのに、サイト 内を右往左往してしまうことも多い。その原因 は、ユーザの欲している情報のある場所に、ユ ーザを効率良く導けていないサイトデザイン とナビゲーションにあると考えられる。このよ うに Web 上では、ナビゲーションが人間と情 報をつなぐ重要な役割を持っている。

本研究では、ウェブ上での情報検索行動にお いて重要な役割を果たすナビゲーションに焦 点をあてる。ナビゲーションに焦点をあてる理 由は、ユーザをいかに必要な情報に導けるかが、 サイトのユーザビリティの良し悪しに大きく 影響するからである。そこで、ユーザの情報探 索行動を行動分析と眼球運動分析することで、 現存するナビゲーションの問題点を明らかに し、必要な人に必要な情報を効率良く提供でき るナビゲーションシステムを検討していく。

\section{2. 実験内容}

本実験で使用したサイトは、国内自動車メー カー7 社である。自動車メーカーのサイトを刺 激として用いた理由は、自動車メーカーのサイ トが、直接の商取引は行われていないが、消費 者が購入の判断材料として用いるオンライ ン・カタログの役割を担っているためである。
そのため、ユーザが必要な情報に容易にアクセ スできるナビゲーションシステムを明らかに する必要があると考えられるためである。

各社のサイトにおいて、同様のタスクを与え、 その際の眼球運動を測定した。使用した眼球運 動測定装置は、非接触型眼球運動測定装置 FreeView（竹井機器工業(株)）である。被験者 は、視覚に異常のない 10 人である。

\section{3. ウェブナビゲーションの現状}

上記の実験で得られたビデオ映像をもとに各 サイトにおける、タスク処理に要したマウスの クリック数と最も効率良く検索できる場合の 最短クリック数を比較してみた（表 1 ）。

\begin{tabular}{|c|c|c|}
\hline サイト名 & 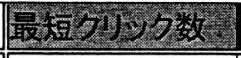 & \\
\hline$A$ 社 & 2 & 6.8 \\
\hline$B$ 社 & 1 & 3.8 \\
\hline C 社 & 6 & 10.7 \\
\hline$D$ 社 & 3 & 6.1 \\
\hline$E$ 社 & 3 & 4.7 \\
\hline$F$ 社 & 3 & 5.2 \\
\hline$G$ 社 & 2 & 5.8 \\
\hline
\end{tabular}

（表 1 タスク処理に要したクリック数）

この結果は、ウェブ上におけるナビゲーショ ンの実状を示している。表からからすべてのサ イトにおいて、ユーザが情報検索をする際に何 らかの間違いをし、サイト内を遠回りしている ことが読み取れる。このことは、同時に現存の ものよりも、さらに効率の良いナビゲーション を考える意義が十分にあることも示している。 


\section{4. 結果と考察}

実験の結果から、各サイト内で用いられてい るナビゲーションシステムを位置・形状などに より、以下の 4 つパターンに分けて分析する ことができた。

$$
\begin{array}{ll}
\text { (1) ロールオーバー型 (2)分離型 } \\
\text { (3)二段型 } & \text { (4)中央ワイド型 }
\end{array}
$$

各ナビゲーションの型によって、それぞれ違 う視探索の典型例が認められた。以下に、それ ぞれのパターン別に明らかになった視探索パ ターンの典型例を示す。

(1) ロールオーバー型

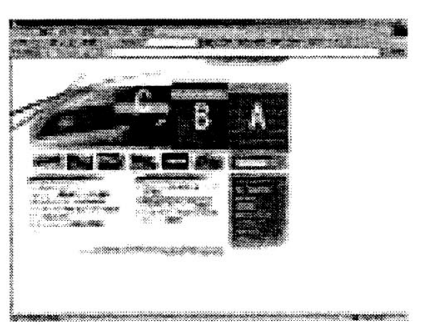

これは、ナビゲ ーションの特定 の位置にマウス ポインタを持っ ていくことで、次 のナビゲーショ ンが出てくるタ イプである。ユーザが実際にアクションを起こ すまで、次の選択肢が出てこないため、視線が ナビゲーションに集中する。そのため、比較的 容易に情報検索活動が行われる傾向が認めら れた。視線が $(A) \rightarrow(B) \rightarrow(C)$ と安定している。

(2) 分離型

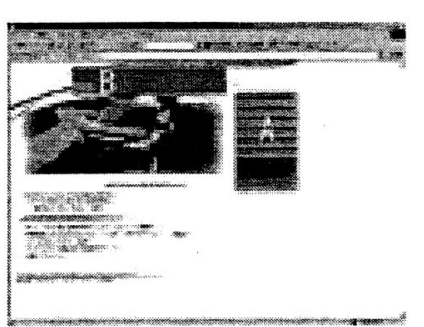

このタイプは、 目的別に分けら れたナビゲーシ ヨンが同ページ 内に分割して存 在する。この場合、 ユーザは面積の

広い（A）に視線を向ける傾向が認められた。 本実験では、面積の小さい（B）に選択すべき 項目あったため、（A）で多くの時間を費やし、 誤動作が増える傾向が認められた。

(3) 二段型

これは、同一の場所にありながら、デザイン

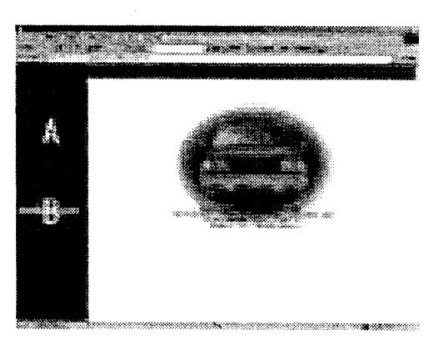

や色で $2 つ に$ 分 けられるタイプ である。これもタ イプ(2)同様、面積 的に大きく占め ている（A）に視 線が集中し、クリ ックすべき場所がある小さい部分（B）に視線 が向けられにくい傾向が認められた。

(4) 中央ワイド型

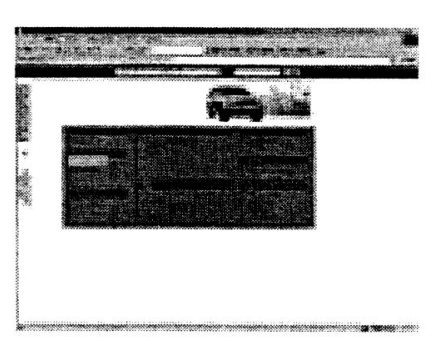

ナビゲーション がページの広い部 分を占めているタ イプである。この ようなページでは、 間違いやタスク処 理速度の遅れが他 のナビゲーションより目立った。考えられる要因 は、ナビゲーションが広範囲に及ぶため、情報検 索活動を広範囲にわたって行う必要があること が挙げられる。また、ユーザは広範囲から目的の 情報を探す必要があることから、その分視線の移 動速度は速かった。また、視線移動速度の上昇に 伴い、個々の情報に対する集中の減少のため、ク リックすべき情報に視線を向けているにも関わ らず、それを認知せず、クリックしない特徵が認 められた。

\section{5. まとめ}

実験結果より、タイプ別に特徵の異なる視探 索パターンが検出されたことから、ナビゲーシ ヨンのデザインが情報検索時の眼球運動に大 きく影響していることが明らかになった。また、 効率良くユーザを誘導するためには、特定の 1 ケ所に視線が集中するシステムが有効的だと 考えられる。これらのことを考慮することで、 ユーザの精神的、肉体的負担の少ない情報コミ ユニケーションが実現されると考える。 